\title{
Aspectos políticos da economia do desenvolvimento e do subdesenvolvimento em Wilson Cano *
}

\author{
Evaldo Gomes Júnior ** \\ Pietro Caldeirini Aruto *** \\ Vitor Hugo Tonin ${ }^{* * *}$
}

\begin{abstract}
Resumo
O presente artigo objetiva analisar a economia política da América Latina a partir do pensamento do professor Wilson Cano. Este pensador se debruçou sobre o subdesenvolvimento da região durante toda sua trajetória intelectual, especificamente do Brasil. Por isso mesmo, também relacionou em sua análise, níveis mais gerais do (sub)desenvolvimento econômico com o caráter específico da reprodução capitalista nos espaços subnacionais. A metodologia parte da análise dos seus escritos e de como eles se conectam com a tradição crítica da economia política da chamada Escola de Campinas e da Cepal. Argumentase que Wilson Cano enfrenta o liberalismo econômico com rigor, tanto no pensamento econômico como na arena política em torno do Estado nacional. Ao final, debate-se a categoria capital mercantil, central em sua análise, para evidenciar sua coerência histórica em detrimento de alguns limites teóricos.
\end{abstract}

Palavras-chave: Cano, Wilson, 1937-2020, América Latina, Subdesenvolvimento, Nação e região.

\section{Abstract \\ Political aspects of the economics of development and underdevelopment economy according to Wilson Cano}

This paper aims to analyze the political economy of Latin America from the perspective of Professor Wilson Cano. Building on from the ECLAC methodological tradition, he associated general determinants of the international economic system with the specific capitalist reproduction conditions in each country. Throughout his works, he focused on the economic underdevelopment of the Brazilian economy and of the different regions. As neoliberalism ascended as the new official agenda for underdevelopment countries, Cano wrote numerous articles criticizing its effects over the productive structure and increasing inequality. Methodologically, current analysis emphasizes his writings and how they relate to the critical tradition of political economy of the "Campinas School of Economy" and the ECLAC. It is shown how Cano criticizes neoliberalism, both in terms of economic thought and the national political arena. The article concludes with a debate on the mercantile capital category, due to its relevance in his analysis, to evidence both its historical coherence and some theoretical limits.

Keywords: Cano, Wilson, 1937-2020, Latin America, Underdevelopment, Nation and region. JEL O1, O2, O54, R1, R11.

${ }^{*}$ Artigo recebido em 30 de março de 2021e aprovado em 21 de julho de 2021.

** Professor do Instituto de Estudos em Desenvolvimento Agrário e Regional da Universidade Federal do Sul e Sudeste do Pará (IEDAR-Unifesspa), Marabá, PA, Brasil. E-mail: evaldo.gomes@ unifesspa.edu.br. ORCID: https://orcid.org/0000-0002-0987-1895.

${ }^{* * *}$ Economista da Secretaria de Desenvolvimento Econômico e Sustentável de Santa Catarina (SDE/SC), Florianópolis, SC, Brasil. E-mail: pietro.aruto@gmail.com. ORCID: https://orcid.org/0000-0002-4693-0292.

${ }^{* * * *}$ Doutorando em Desenvolvimento Econômico na área de Economia Regional e Urbana do Centro de Estudos em Desenvolvimento Econômico do Instituto de Economia da Universidade de Campinas (CEDE/IE-Unicamp), Campinas, SP, Brasil. E-mail: vitorht@gmail.com. ORCID: https://orcid.org/0000-0002-3206-4143. 


\section{Introdução}

Ya fuese por el prestigio del organismo que lo sostenía, ya por el brillo de los intelectuales que se encargaran de teorizarlo, el desarrollismo alcanzó notable influencia a nivel de gobierno (...) Simultáneamente, marcó el inicio de un pensamiento original estructurado en América Latina independientemente de expresiones individuales, que se habían manifestado desde los años veinte - y abrió un debate, en pie de igualdad, con las ciencias sociales que se producían en los centros capitalistas (Rui Mauro Marini, 1999, p. 12).

A trajetória da economia brasileira após a recessão de 2015-2016 não dá sinais de superação. Antes mesmo dos impactos econômicos e sanitários da epidemia do COVID-19, o quadro era de uma estagnação econômica crônica, com baixa taxa de investimento, ociosidade na indústria, estagnação do rendimento familiar e do PIB per capita. Por sua vez, a política econômica adotada desde a recessão aprofundou ainda mais a situação, ao privilegiar a austeridade em detrimento dos gastos e investimentos públicos. Na verdade, a política econômica se soma a outras tantas medidas adotadas, desde então, que procuram aprofundar o projeto neoliberal, como as reformas trabalhistas, a do teto dos gastos e da previdência.

As consequências da crise sobre as famílias trabalhadoras não poderiam ser mais trágicas, com aumento do desemprego, da informalidade e queda do rendimento. A tragédia é ainda maior ao se detalhar os dados nacionais, quando eles apontam toda uma ordem de desigualdades, de renda, de propriedade, de acesso a serviços públicos, e também desigualdades de gênero, de cor/etnia e regional.

Para além de uma questão meramente conjuntural, a crise brasileira dos últimos anos apenas coloca em primeiro plano as características históricas do subdesenvolvimento econômico, seja pela regressão da estrutura produtiva-industrial das últimas décadas, seja pelos níveis absurdos de concentração de renda/propriedade, seja pela inserção passiva do país no sistema econômico internacional. Essa perspectiva crítica, tão ausente do debate econômico dominante, sempre foi promulgada pelo economista Wilson Cano, professor fundador do Instituto de Economia da Universidade Estadual de Campinas e pesquisador emérito do CNPq. Na sua visão, mesmo os fenômenos econômicos mais superficiais estão vinculados a condicionantes histórico-estruturais, que remontam à própria formação da economia capitalista brasileira durante o século XIX, dentro das assimetrias econômicas e produtivas internacionais que a Cepal conceituou como "sistema centroperiferia".

Herdeiro e defensor dessa tradição cepalina, Wilson Cano, durante sua trajetória acadêmicointelectual, sempre conciliou o compromisso científico na investigação em torno das manifestações do subdesenvolvimento econômico com a denúncia das suas desigualdades e de seus interesses de classes por trás dos rumos da economia, tanto no Brasil como no continente latino-americano. Mais do que isso, considerava essa postura política como essencial para todo os economistas, ao ampliar sua capacidade investigativa e analítica, por conferir uma visão ampla da realidade econômica e social.

Ao manter suas convicções estratégicas e coerência intelectual, Wilson Cano se torna nesse momento um crítico vigoroso das políticas econômicas promovidas nos últimos 30 anos no Brasil e 
na América Latina. É essa produção crítica ao modelo de desenvolvimento latino-americano que se busca analisar neste artigo, nas seguintes dimensões: a) mundial, ressaltando a América Latina como unidade de análise e resgatando sua visão histórica do imperialismo e de sua fase atual: o neoliberalismo enquanto ideologia e projeto de desenvolvimento; b) Subdesenvolvimento econômico enquanto princípio metodológico, uma vez que o "sistema centro-periferia" nos vários padrões de acumulação conforma uma série de desigualdades internamente aos países latino-americano, como é o caso das desigualdades regionais durante o processo de industrialização, fenômeno esse tão profundamente analisado por Wilson Cano; c) na crítica à ofensiva neoliberal e propostas para resistência, com ênfase na crise estrutural que o neoliberalismo produz há quatro décadas e na deterioração ideológica das ciências econômicas, oriunda dessa dominação neoliberal. Feitas essas considerações introdutórias, as seções que se seguem tratam, respectivamente, de cada uma dessas dimensões ressaltadas anteriormente. Ao final, procura-se sintetizar a trajetória acadêmica-intelectual do professor Wilson Cano e seu legado para as ciências sociais do continente latino-americano.

Metodologicamente, a exposição sintética e dirigida da crítica de Wilson Cano sobre os rumos do subdesenvolvimento econômico brasileiro na atualidade fez-se com o resgate das suas obras, como livros, textos, artigos e anotações em sala de aula. O resgate teve como princípio metodológico a relação entre esses diversos temas com o pensamento cepalino, o qual constitui uma unidade analítica presente durante as mais de cinco décadas de atuação do professor Wilson Cano. Procurou-se explicitar em cada dimensão os conflitos econômicos e políticos e os interesses de classes decorrentes da própria manifestação do subdesenvolvimento econômico no seu processo histórico. Por fim, em cada seção, tentou-se recuperar o tom polêmico e crítico dos argumentos, abordagem que o saudoso professor cultivava não apenas por estilo, mas para apontar a seriedade da discussão e explicitar seus desdobramentos econômicos, sociais e políticos.

\section{América Latina: do subdesenvolvimento à crise estrutural neoliberal}

\subsection{A interpretação do subdesenvolvimento econômico: Wilson Cano e a escola de Campinas}

Nas ciências sociais brasileira, Wilson Cano, com sua tese Raízes da Concentração Industrial em São Paulo (Cano, 2007) contribui para a obra fundante da interpretação econômica do Brasil pelo IE/Unicamp, integrada a O Capitalismo Tardio, de João Manuel Cardoso de Mello (Mello, 1982), e Da Substituição de Importações ao Capitalismo Financeiro, de Maria da Conceição Tavares (Tavares, 1972), entre outros. Entre eles, ocorreu uma verdadeira divisão intelectual-acadêmica do trabalho.

A João Manuel coube estabelecer as bases históricas da formação econômica do Brasil, buscando refutar, recuperando a interpretação da dependência latino-americana de Fernando Henrique Cardoso e Enzo Faletto (2000), as teses da Comissão Econômica para América Latina e o Caribe (Cepal). Para tanto, propõe que a história econômica do Brasil se divide em um primeiro período colonial e que foi superado por uma economia primário-exportadora, mediada pela economia mercantil ${ }^{1}$, dominada pelo capital comercial-nacional - visto que se tratava de um país formalmente independente. Assim, por meio da economia mercantil escravista cafeeira nacional se completou a

(1) A noção de capital mercantil acompanha as análises da Escola de Campinas em várias dimensões, como veremos ao longo deste artigo. 
nacionalização das decisões de investir e viabilizou-se o assalariamento, dando origem a economia exportadora assalariada, fundamentais para o crescimento industrial desde o início do século XX, impulsionado posteriormente pelos estrangulamentos externos da crise de 1929 e pela ação do Estado Nacional.

Esta interpretação dialoga e aproveita os trabalhos anteriores de Maria da Conceição Tavares (2000), sobre o período de 1930 a 1970 . Nesse período a economia brasileira é caracterizada por um processo de industrialização intenso, mas, até 1955, ainda restringida pela capacidade de financiamento das importações de máquinas e equipamentos, e determinada pelos níveis de acumulação do setor primário exportador e, posteriormente, por uma fase de industrialização pesada, executada pela sagrada aliança Estado, capital nacional e capital estrangeiro, que nos levou a completar a nossa industrialização retardatária, mas ainda com restrições de financiamento, apesar dela não ter atendido às demandas míticas desenvolvimentistas (Mello, 1982, p. 122 ).

Nesse grande tema de pesquisa sobre a formação e determinantes da economia nacional segundo a escola de Campinas, coube a Wilson Cano coube analisar a industrialização e os desequilíbrios regionais, tendo como principal tarefa combater a tese "da ação de um suposto imperialismo paulista sobre as economias regionais" (Cano, 2007a, p. 10). Para isso, ele investigou as razões da concentração industrial em São Paulo defendendo que as causas das heterogeneidades se encontravam no período anterior a 1930. Para Cano, as relações de produção que sustentaram a especificidade do complexo cafeeiro paulista viabilizaram um início mais dinâmico da industrialização em São Paulo.

Ao fim da década de 1970, com as mudanças no sistema econômico internacional e escalada das taxas de juros, a industrialização sofre um duro revés. O problema do Brasil era a marcha forçada e autoritária com que a ditadura militar buscava não somente completar a industrialização sem superar os obstáculos de financiamento, mas também engajar-se na chamada terceira revolução industrial.

Entretanto esse processo, em grande parte fracassou. Vários de seus empreendimentos não puderam seguir à frente, justamente porque o Plano era megalômano, suas necessidades de financiamento eram internamente insolúveis e os arranjos políticos e institucionais entre o capital estatal, privado nacional e o capital estrangeiro não puderam ser satisfatoriamente equacionados (Cano, 1990, p. 131).

Assim, a luta pela democracia se tornava também a luta pelo resgate da coordenação democrática do processo desenvolvimento e na socialização dos benefícios trazidos pela industrialização.

Entretanto, não foi o que se viu. Ao final dos anos 1980 e, particularmente nos anos 1990, a burguesia paulista abandona o projeto desenvolvimentista e adere paulatinamente ao ideário neoliberal. $\mathrm{O}$ debate econômico perde pluralidade, a heterodoxia perde espaço e a hegemonia do mercado financeiro se instala. A partir daí, a produção intelectual de Cano se amplia, para além do regional, e passa a discutir também os problemas nacionais e latino-americanos, vinculando-os 
diretamente ao debate regional estabelecido na divisão de trabalho anterior ${ }^{2}$. Antes de aprofundar o debate sobre o impacto do neoliberalismo, cabe aprofundar a visão de Wilson Cano sobre a especificidade do continente latino-americano e sua trajetória frente aos determinantes do sistema econômico internacional.

\subsection{América Latina como unidade de análise e a nova fase imperialista}

Para Wilson Cano, o que garante a América Latina como unidade de análise é o colonialismo e o imperialismo, este último vigente até hoje. Admitir isso jamais impediu Cano de apreender especificidades concretas de cada economia nacional da região. Especificidades que conferem tempos e espacialidades distintas a cada caso nacional. Esse recurso fundamental da ciência social - realizar abstração em diferentes níveis de análise partindo dos fatos empíricos - está cada vez mais raro nas análises acadêmicas, seja pela hegemonia neoclássica nas ciências econômicas com seu método lógico-dedutivo e utilitarista, seja também pela predominância de novas perspectivas pós-modernas, em que só o empírico interpretado subjetivamente pelos indivíduos importa.

Para Cano (1999, p. 288), entre 1929 e 1979 “uma parte da América Latina gozou de um maior grau de soberania na condução da política econômica de desenvolvimento". Contudo, isso não quer dizer que, para Wilson Cano, o imperialismo tenha sido suprimido das relações internacionais durante a industrialização. Muito influenciado pelas obras de John A. Hobson (1985) e Lênin (2005), cobradas no curso de Desenvolvimento Econômico na pós-graduação, as características do imperialismo, como colonialismo, militarismo, exportação de capitais, hegemonia do capital financeiro, monopólios e cartelização, condicionaram as transformações econômicas no continente. Quer dizer, isso sim, que a disputa geopolítica entre as potências do imperialismo de 1929 até a segunda guerra e, posteriormente, entre os blocos capitalista e socialista, permitiu a formação de uma política econômica na periferia latino-americana que tirou proveito dessa disputa ${ }^{3}$.

É nesse período histórico de 1930-1980 que foi possível o avanço da industrialização em alguns países periféricos. Isto não quer dizer que estava livre das pressões e das sobredeterminações imperialistas, mas sim, que havia maior margem de atuação do planejamento dos processos de acumulação, diante das disputas geopolíticas entre o império liberal ocidental e o socialismo sinosoviético. Disputa essa que foi marcada por diferentes fases desde o imediato pós-guerra, passando pela vitória da Revolução Chinesa e pela Guerra da Coréia até a implantação das ditaduras preventivas latino-americanas. A partir de 1979, a nova política monetária dos EUA compõe uma nova ofensiva imperialista. Com o mercado de eurodólares, os EUA haviam passado de maiores credores para os maiores devedores do mundo e já estavam tecnologicamente atrasados em relação ao Japão e à

(2) Os livros e outras publicações do professor Wilson Cano encontram-se reunidas, em grande parte, no sítio dedicado à sua obra: https://www.wilsoncano.com.br. Além dele, recomenda-se o acesso ao sítio do Centro de Estudos em Desenvolvimento Econômico do IE/Unicamp, que reúne teses e dissertações orientadas por ele: https://www.eco.unicamp.br/cede.

(3) Cabe registrar que imperialismo, enquanto categoria estrutural do sistema econômico internacional capitalista, aparece mais frequente nos escritos de Wilson Cano somente após a crise da industrialização e hegemonia do projeto neoliberal, com a subjugação do Estado Nacional ao seu programa, conforme o autor analisou, dentre outros textos, em Cano (1996). Nos livros originados das suas teses de doutorado e de livre docência (Cano, 2007a e 2007b), por exemplo, não há menção da categoria de imperialismo, a não ser pejorativamente, no caso do suposto imperialismo paulista. A despeito da maior utilização da categoria por Wilson Cano a partir de 1980, em nenhum momento ele incorpora à análise econômica do imperialismo a partir da lei do valor e do mais-valor em sua manifestação planetária. 
Alemanha. Essa crise de hegemonia não poderia ser solucionada em favor destes últimos países, pois eles não "dispunham de língua, moeda e exércitos de poder universal" (Cano, 1995, p. 194, itálicos do autor). Assim para retomar sua hegemonia, os EUA precisavam solucionar seus problemas financeiros e ganhar tempo - "variável que normalmente o economista não maneja muito bem" (Cano, 1995, p. 192) - para alcançar seus rivais na corrida tecnológica.

Promovem, então, uma nova ofensiva imperialista cujos ideais de políticas econômicas vinham sendo experimentadas de forma precoce no Chile, a partir do golpe empresarial de 1973, e que ganham terreno fértil no mundo ocidental com a queda do muro de Berlim e a dissolução da União Soviética. Desde então, o modelo hegemônico implementado nos países da América Latina se caracteriza por um viés (neo)primário-exportador sob hegemonia do capital financeiro especulativo, justificado pelas ideias neoliberais. Assim, Cano (1990), já nos primórdios da difusão dessas ideias no continente, denunciava como o neoliberalismo é um projeto ideológico forjado pelos EUA, que necessitavam impor um novo modelo de dominação a fim de superar sua crise de hegemonia do final dos anos 1970 .

Este modelo difundido - mas jamais adotado - pelos EUA, ao contrário do que promete, promove a instabilidade macroeconômica, a desindustrialização, a fragmentação e a heterogeneidade do sistema produtivo, o desemprego e a precarização laboral. Para Cano $(2011 ; 2014)$ este modelo colocou a América Latina, e o Brasil em particular, numa crise estrutural que já dura quatro décadas.

A instabilidade do modelo não se define somente pelas políticas fiscais mais ou menos restritivas, de acordo com a orientação do governo em curso, mas sim pela forma como este modelo insere os países da região no capitalismo mundial. Nisso reside uma das principais contribuições do pensamento econômico do autor com fortes consequências políticas: a consciência de que as chamadas "contas externas" continuam sendo determinantes nas condições do subdesenvolvimento já que expressam as relações centro-periferia. Isto é, a forma como os países latino-americanos estão atualmente subordinados à nova fase imperialista promove condicionalidades fundamentais aos seus processos de desenvolvimento, e os canais pelos quais são transmitidas são as contas de capital e a conta de transações correntes do Balanço de Pagamentos (Cano, 2011; 2014).

Para explicar melhor, exemplifica-se com uma análise concreta baseada na crítica de Wilson Cano à abertura comercial e financeira no Brasil. A âncora cambial do processo de estabilização monetária no Brasil era, na verdade, ancorada em altíssimos juros da dívida pública interna, que acabaram comprometendo o orçamento público no longo prazo. A farra das importações dos anos 1990 nos custou um endividamento interno gigantesco, enquanto a liberação comercial e financeira iniciada nos 1990, ainda em voga, exige uma constante entrada de fluxos de capitais externos. De forma que qualquer crescimento do PIB e da renda um pouco mais elevado, para os padrões neoliberais, impulsiona a demanda por importados acima do equilíbrio do balanço de pagamentos, determinado em grande medida pelas condições financeiras e comerciais externas, elevando o dólar e impactando a inflação.

Hoje, reinventaram a valorização cambial, que impulsiona os juros para cima, aumenta os custos financeiros, inibe o investimento produtivo, altera violentamente a estrutura de preços relativos e fortalece a fogueira da especulação. A menos que a memória inflacionária tenha um curso suficiente de tempo para destruí-la, não há outra saída senão a destruição parcial da riqueza 
privada acumulada nesse processo. Caso contrário, a inflação reprimida "sairá do tapete". Contudo, em qualquer crise cambial de maior vulto, a desvalorização se torna crucial, repondo novamente o processo inflacionário (Cano, 1999, p. 319).

Da mesma forma, qualquer impulso fiscal expansivo que ameace o pagamento da dívida interna afugenta os investidores estrangeiros e promove desequilíbrios nas contas externas, depreciando o câmbio que por sua vez desvaloriza a moeda internamente.

Dizem os otimistas que não teremos maiores problemas com nossas contas externas, não só pelos elevados superávits comerciais que vínhamos obtendo, como também pelos grandes fluxos de investimentos externos que entraram nos últimos anos, aumentando nossas reservas para mais de US $\$ 200$ bilhões e tornando nossa dívida externa pública líquida negativa. (...) É fato que a dívida externa pública, que era de US\$ 88 bilhões em 2005, cai para US\$ 69 bilhões em junho de 2009, mas a privada, nas mesmas datas, saltou de US\$ 82 bilhões para US\$ 130 bilhões, com o que a dívida total - incluindo os financiamentos entre empresas - aumentou, dos US\$188 bilhões em 2005 para US\$ 270 bilhões em junho de 2009. Considerando-se que o capital externo em 31 de agosto de 2009 possuía US\$ 212 bilhões em ações e títulos de renda fixa e que estes, diante de certas circunstâncias, podem ser liquidados em 24 horas, não vejo razão para muito otimismo, diante do colossal aumento do passivo externo (Cano, 2011, p. 353-354).

Por isso que, além de instável, o modelo inviabiliza o crescimento econômico sustentado. Como se observa, Wilson Cano atualiza a categoria analítica fundante do pensamento Cepalino, qual seja, o sistema centro-periferia e suas determinações econômicas. Assim, é na forma como estamos inseridos no mercado mundial que estão colocadas as principais restrições ao nosso desenvolvimento e os desafios da superação ao subdesenvolvimento:

As condições do mercado internacional favoreceram a vinda de amplos fluxos financeiros, ampliando o investimento externo, notadamente em serviços (financeiros, principalmente) e na especulação no mercado de valores. O grande afluxo de divisas causou-nos e causa a grave valorização da taxa de câmbio, pondo ainda mais a descoberto nosso mercado interno de serviços e produtos industriais. Esse efeito "tapa buraco" de nosso Balanço de Pagamentos resultou em forte acumulação de reservas, que atingem hoje cerca de US\$ 370 bilhões. Isso inclusive levou muitos economistas a afirmarem que nossa vulnerabilidade externa diminuiu fortemente, ainda mais que parte importante dos investimentos externos resultou em aplicações em $\mathrm{R} \$$ em títulos públicos e privados. Não se dão conta, na verdade, de que nosso passivo externo líquido triplicou, e que essas bem-aventuradas reservas não têm como contrapartida saldos em transações correntes positivos, e sim saldos financeiros decorrentes do aumento de nossas obrigações externas (Cano, 2014, p. 150).

Assim, o subdesenvolvimento não é mais uma fase ultrapassada por nações emergentes, mas uma estrutura que se reproduz e se mantem na nova fase de dominação neoliberal. Esta é uma das principais contribuições de Cano para a disputa política e econômica da atualidade.

\section{Subdesenvolvimento como princípio metodológico: a questão regional brasileira}

$\mathrm{Na}$ seção anterior, destacou-se o caráter central do subdesenvolvimento econômico para a análise das diversas realidades sociais. O subdesenvolvimento, enquanto a específica inserção econômica da América Latina no sistema econômico internacional, marcado por uma elevada 
disparidade econômico-tecnológica entre o centro e a periferia, está por trás dos processos históricos de transformação das economias periféricas desde o século XIX. Nesse sentido, Wilson Cano reivindicava a interpretação da escola de Campinas quanto aos rumos da industrialização brasileira conciliando com a tradição e metodologia cepalina, sobretudo na heterogeneidade do sistema econômico internacional. De fato, Cano vai revelar uma certa ambiguidade em sua interpretação, aproximando elementos de ambas ${ }^{4}$.

Essa visão estrutural do subdesenvolvimento econômico em Wilson Cano, sua relevância conjuntural, sua denúncia e o combate ao projeto neoliberal, desdobrou-se em vários objetos de estudo, não apenas a economia brasileira. Dentre eles estão a questão regional e o espaço urbano no Brasil. De fato, ao conferir a produção bibliográfica do Wilson Cano, a temática possui uma preponderância: dos quinze livros de sua autoria ou organizados por ele listados em sua página na internet, somente três não incorporavam explicitamente a dimensão regional/urbana ${ }^{5}$.

Nesse sentido, essa seção fornece uma visão geral da questão regional e da centralidade da categoria capital mercantil na discussão do atraso de alguns setores e regiões no desenvolvimento capitalista nacional, segundo a interpretação do professor Wilson Cano. O intuito é demonstrar como a análise do subdesenvolvimento econômico se desdobrava metodologicamente para outros níveis de mediação espacial, abordagem essa que influenciou uma geração de pesquisadores.

Segundo Wilson Cano (2007a, p. 11-13), a questão regional Brasileira surge, enquanto problemática nacional, a partir da década de 1950 com o avanço da industrialização no Plano de Metas e com a constatação, pelas estatísticas oficiais, da concentração da produção industrial em São Paulo e a ampliação dos desequilíbrios regionais.

A "Questão Regional", quer dizer, o problema dos desequilíbrios regionais da economia brasileira, aflora definitivamente à consciência nacional entre fins da década de 1950 e início da seguinte. Não é difícil atinar com as razões que determinaram o amplo debate em torno do tema (Cano, 2007a, p. 19).

Não obstante essa tomada de consciência, os primeiros estudos sobre as desigualdades regionais durante a industrialização apresentavam uma lacuna: as origens do atraso de algumas regiões não se explicam pela trajetória durante a industrialização, mas sim, remontam às três primeiras décadas do século XX (Cano, 2007c). A tese central do argumento era que a maior dinâmica industrial paulista estava assentada na formação do complexo capitalista cafeeiro, no desenvolvimento de relações de capitalistas de produção assalariadas, que proporcionaram a ampliação do mercado interno e uma incipiente produção industrial.

(4) Um dos exemplos dessa conciliação pode ser visto na utilização do conceito de industrialização restringida de Maria C. Tavares e João M. C. Mello em detrimento de substituição de importações: "Com a revisão da história econômica do Brasil que se vem fazendo, esse período passou a se denominar de industrialização restringida, porque, de um lado, da mesma forma que na conceituação de 'substituição de importações', a reprodução ampliada de seu capital produtivo depende ainda do setor exportador, que gera as dívidas necessárias às importações dos bens de produção; restringida também porque, não possuindo expressivo compartimento produtor de bens de produção, 'não marcha sobre seus próprios pés', isto é, não tem condições de autonomia para sua reprodução. Em que pese a diferença teórica entre os conceitos de 'substituição de importações' e de 'industrialização restringida', cabe esclarecer que qualquer que seja a conceituação teórica, o corte temporal deve ser feito para o período 1930-55” (Cano, 2007b, p. 334-335).

(5) Disponível em: https://www.wilsoncano.com.br/. Acesso em: 10 mar. 2021. 
A investigação desse fenômeno marcou a trajetória acadêmica do professor Wilson Cano, desde sua tese de doutorado defendida em 1975 no IE/Unicamp, publicada como livro em "Raízes da Concentração Industrial em São Paulo" (abrangendo o período 1850-1929), pela sua tese de livre docência, dez anos depois, intitulada "Desequilíbrios regionais e concentração industrial no Brasil (1930-1970)" e, ainda, em 2007, já como professor titular aposentado, com a publicação do livro "Desconcentração Produtiva Regional do Brasil: 1970-2005". Tem-se, assim, uma análise que cobre mais de 150 anos do desenvolvimento capitalista brasileiro e seus desdobramentos regionais, na melhor tradição do estruturalismo latino-americano.

\subsection{Análise histórica da dominação regional paulista}

Uma exposição mais abrangente da interpretação do professor Wilson Cano sobre a questão regional em toda sua obra extrapola o objetivo deste artigo. A discussão, nesta seção, será dirigida ao período de transição entre a economia-primário-exportadora brasileira e o início do processo de industrialização, ainda durante a fase da industrialização restringida (1930-1955). Com a integração do mercado nacional, como pré-condição para a industrialização, os diversos complexos regionais espalhados pelo Brasil sofrem a ação de dois movimentos: "o antigo, decorrente da manutenção de uma estrutura primário-exportadora; e o novo, decorrente da ação comandada pelo centro dominante nacional, via dominação dos mercados e do processo de acumulação de capital” (Cano, 2007b, p. 10).

Até meados da década de 1920, não se pode falar propriamente de uma integração do mercado nacional. Ainda que alguns produtos tivessem uma relativa circulação pelo território, - como o açúcar e algodão do Nordeste o charque e a banha do Rio Grande do Sul, os tecidos de São Paulo e Rio de Janeiro -, a determinação do nível de renda e produto dependia, em última instância, do mercado externo, com algumas regiões se inserindo mais no comércio internacional do que outras. A restrita integração regional e a preponderância dos mercados externos na realização da produção permitiram o surgimento de atividades industriais incipientes e complementares à economia primárioexportadora. Ainda que em São Paulo essas atividades contassem com melhores condições para se desenvolverem, as diversas regiões brasileiras apresentaram uma produção industrial não desprezível. Segundo estimativas de Wilson Cano (2007a, p. 300), em 1919, São Paulo concentrava 31\% da produção industrial brasileira, seguido pelo antigo Estado da Guanabara $(20,8 \%)$, Nordeste $(16,1 \%)$ e $\operatorname{Sul}(16,2 \%)$.

A partir de então, o crescimento industrial paulista seria expressivo, conforme os dados do Censo Industrial de 1939 revelam (Cano, 2007a, p. 300): São Paulo passa a concentrar 45,4\% da produção industrial, por sua vez, Guanabara (17\%), Nordeste (10,4\%) e Sul (13,8\%) perdem participação na estrutura industrial, nesses primeiros anos do processo de industrialização por substituição de importação. A dinâmica industrial paulista entre 1919 e 1939 está associada a condições estabelecidas durante a década de 1920 e, também, àquelas pós-crise de 1929 e revolução de 1930. No primeiro caso, a década de 1920 assistiu a uma sobreinversão industrial e cafeeira em São Paulo, fruto da política de defesa do café (permanentemente adotada a partir 1922) que permitiu, por um lado, a manutenção do preço em termos razoáveis até 1929, por outro, a transferência de recursos financeiros para o setor industrial via setor bancário. Ao final da década, a sobreinversão, somada às demais características da economia paulista (mercado interno, assalariamento, infraestrutura, rede de cidades), consolidou ainda mais a posição industrial de São Paulo, tornando- 
se o único Estado, segundo Cano (2007b, cap. 5), a reunir as condições para apresentar uma dinâmica industrial à frente da sua demanda local, dirigindo-se para outras regiões do país.

Com a crise de 1929 e a revolução de 30, houve uma transformação da estrutura do Estado e reorientação da política econômica, enquanto processo que marca a emergência da burguesia industrial no bloco de poder da classe dominante. Para fazer frente à queda do preço internacional do café, o governo promove uma desvalorização cambial e retenção de estoques, em sua maior parte, por meio de créditos públicos. A ampliação do déficit público e a desvalorização cambial promovidas, enquanto políticas anticíclicas, permitiram manter o nível de demanda da economia. Mais importante que isso, a manutenção do nível de renda e as dificuldades de importação com a crise permitiram que uma maior parte da demanda por bens de consumo fosse assistida pela produção industrial e, nesse processo, a indústria paulista apresentou maior vantagem graças ao nível de ociosidade da produção durante a sobreinversão da década anterior. Em outras palavras, o período é marcado pelo início, no Brasil, do que posteriormente se denominaria como industrialização por substituição de importação.

A ascensão da indústria como principal setor na determinação do nível de renda no Brasil no início da década de 1930 repercutiu sobre as economias regionais. Aquelas regiões em que a indústria não se desenvolvera (relativamente) previamente contaram apenas com a exportação para o mercado mundial como principal mecanismo de geração de renda, o que era problemático, tendo em vista a crise no comércio mundial pós-1929. Aquelas regiões que já contavam com estabelecimentos industriais puderam se beneficiar das mudanças pós-1930, principalmente São Paulo, que já avançava timidamente na instalação de setores de bens de produção. Mais do que apenas um maior crescimento industrial, a indústria em São Paulo foi o setor responsável pela superação da crise e, para tanto, foi fundamental a interação e dominação dos mercados periféricos:

A série do comércio entre as duas regiões [São Paulo e o resto do Brasil] entre 1928 e 1939, em termos reais, confirma o importante papel desempenhado pela integração do mercado nacional: São Paulo recuperava-se do revés no mercado internacional, quase duplicando suas exportações para o restante do país. Embora a periferia nacional também tivesse expandido (em 41\%) suas vendas ao mercado paulista, o fez em proporção bem menor do que o observado para São Paulo (Cano, 2007b, p. 209).

Para esse processo de integração e dominação do mercado nacional pela indústria paulista foi fundamental as transformações na estrutura do Estado Nacional. Mesmo diante de interesses por vezes conflitantes entre as classes e frações de classes regionais, a questão que se apresentava para o Estado e as diversas elites, sobretudo as paulistas, era integrar para crescer e evitar a estagnação. A integração exigia uma reestruturação do Estado no sentido de homogeneizar as barreiras físicas (transportes marítimos e terrestres), fiscais (impostos estatais) e laborais (regulação da força de trabalho). A transformações promovidas consolidaram ainda mais a posição hegemônica de São Paulo na competição industrial intercapitalista. Dessa forma, a fins da década de 1930, São Paulo consolidou-se como maior polo industrial no Brasil, integrando e dominando o mercado nacional.

\subsection{Aspectos políticos do método de análise regional}

O método analítico de Cano que recuperamos parcialmente e que pode ser encontrado em textos como Cano (2007a; 2007b; 2007c) ou, mais especificamente, no artigo escrito em conjunto 
com Leonardo Guimarães Neto (Cano; Guimarães Neto, 1989), também presente em seu artigo sobre as novas determinações da questão regional e urbana a partir de 1980 no Brasil (Cano, 2010), mostram que, em última instância, Cano estabelece as consequências imediatas sobre a realidade concreta a partir do subdesenvolvimento. Entende, portanto, que o debate político em torno do desenvolvimento deve inserir os elementos espaciais da organização social e produtiva da nação.

Em razão de sua dimensão territorial, de sua formação econômica fundamentada em distintos produtos e ciclos de exportação, a partir dos quais foram criados espaços econômicos ou "regiões" com diferentes relações de produção e dinamismo, o Brasil constitui um país privilegiado para o estudo do desenvolvimento desigual do capitalismo. Formado por "arquipélagos regionais", assiste-se, nos últimos cem anos, a um processo intenso de formação do mercado interno nacional, de integração econômica das regiões, com distintos graus de desenvolvimento, e de constituição de uma estrutura produtiva complexa e hierarquizada (Cano, 1989, p. 167).

Cano estabelece que as questões regionais e suas derivações em torno da urbanização e dos problemas agrários são problemas típicos do desenvolvimento das forças produtivas e das relações sociais de produção capitalista num país. Desta maneira, antecedente a essas mediações espaciais, está presente a questão da constituição da nação. Mais especificamente, como uma nação de passado colonial e inserção dependente na expansão capitalista mundial pode se tornar uma nação autônoma e soberana?

Uma leitura superficial deste autor poderia levar à conclusão de que o processo de industrialização seria capaz de atualizar a dinâmica capitalista das economias latino-americanas nos termos das economias centrais. Por vezes o autor trata a modernidade ocorrida no Brasil por meio do processo de industrialização como virtude, para logo depois apresentar suas limitações, expressando as contradições envolvidas no processo de industrialização dependente.

Finalizando, torno a lembrar que é através da ação do Estado, distribuindo as benesses geradas por esses expedientes, que as elites agrárias brasileiras - no atraso ou na modernização, em São Paulo ou na periferia - perpetuam seus ganhos especulativos, e seu político e econômico calcado na propriedade fundiária e na exploração de um exército de miseráveis trabalhadores rurais. Hoje, fazem avançar ainda mais sua "modernidade", expandindo ainda mais a fronteira itinerante, e, com isso, ampliando sua inserção externa, não tanto para dinamizar suas exportações, mas, principalmente, para usufruir dos excelentes negócios e negociatas propiciados pela desregulamentação do câmbio e da livre entrada e saída de capitais do país (Cano, 2002, p. 142, grifo do autor).

Cano, desta forma, mostra a necessidade do processo de industrialização como condição necessária para o desenvolvimento econômico das nações periféricas latino-americanas, mas não suficiente como mecanismo de emancipação nacional.

Refletir em torno das mediações espaciais é refletir em torno da hierarquização e das heterogeneidades impostas pelo capitalismo entre os espaços de acumulação e sociabilidade mediados pelo próprio capital. Se o desenvolvimento das forças produtivas nas nações a submete a processos acelerados de urbanização, devido à preservação do latifúndio, êxodo rural e superdimensionamento do exército industrial de reserva, esta mesma urbanização não será idêntica entre os chamados países centrais e periféricos. Se o acionamento de regiões de maneira hierárquica e desigual no processo 
nacional de acumulação de capital é a regra, não justifica, entretanto, acreditar que existirão mecanismos automáticos de convergência de renda entre centros capitalistas subnacionais dos países centrais e periféricos. Se o capital incorpora a agricultura e a industrializa como setor essencial para alimentar as cidades, na periferia do capitalismo esta incorporação permanece truncada e conservadora, sem criar condições de democratização do acesso à terra e de desenvolvimento de pacotes tecnológicos em acordo com as condições específicas destes países. Há, no máximo, assimilação de tecnologias alheias a uma produção sustentável nas zonas tropicais como meio de intensificação da produção agropecuária exportadora.

O rigor do método permite aliar a análise espacial com a correta periodização, derivada dos processos mais gerais de acumulação de capital e sua vinculação específica nos países e em regiões. Cano e Guimarães Neto (1989) é um exemplo evidente quando observamos que os padrões de reprodução do capital refletidos na economia brasileira são derivados de mudanças de padrões de acumulação no mundo: i) economia primário-exportadora de dominação mercantil alia-se à primeira fase de capitalismo monopolista do padrão-ouro; ii) processo de industrialização restringida e pesada alia-se ao interregno entre crise econômica de 1929 e à fase excepcional de desenvolvimento produtivo, conhecido como "Anos dourados do capitalismo"; e iii) crise da dívida e início dos processos de desestruturação produtiva alia-se à retomada da hegemonia imperialista dos Estados Unidos e posterior propagação do receituário neoliberal.

No Brasil, estes períodos distintos da acumulação capitalista em sua fase monopolista têm resultados distintos nos espaços subnacionais de acumulação, porém, estas transformações são mediadas pela inserção da economia nacional na divisão internacional do trabalho. Se esta inserção no capitalismo mundial gera hierarquias e heterogeneidades a nível global, entre os países e blocos econômicos, também é possível definir o espaço nacional como um espaço hierarquizado e heterogêneo. Neste caso, Cano mantém a centralidade destas hierarquias em sua análise em termos metodológicos similares à de Furtado (1959) e Frank (1966), por exemplo, nos quais a questão regional é um processo de mediação entre a forma de inserção dos países no capitalismo mundial e as dimensões urbanas e rurais. Entretanto, compartilhar destes supostos conceituais de uma ordem capitalista hierarquizada não significa chegar as mesmas conclusões analíticas. De fato, a interpretação de Cano sobre a dominação paulista é divergente da de Furtado e leva a conclusões políticas opostas às de Frank. Vejamos por que na próxima seção.

\subsection{Dominação regional e o papel do capital mercantil nas primeiras décadas de industrialização restringida}

Estabelecida a hegemonia econômica paulista, tal como recuperado na seção 2.1, os efeitos dessa dominação para a periferia são diversos, segundo Cano (2007b), a depender da estrutura produtiva das regiões e dos setores diante da trajetória das características do processo de industrialização em questão (restringida ou pesada). Sinteticamente, ele aponta três principais efeitos. O primeiro é o efeito de estímulo, quando o aumento da demanda interna estimula a produção de bens industriais das regiões periféricas, não necessariamente competindo com as do polo paulista, muitas vezes complementares a ele. Os efeitos de inibição/bloqueio caracterizam-se quando os bens industriais produzidos na região periférica para atender sua demanda local foram planejados para ser direcionados para o mercado nacional, mas não puderam ser efetivados ou, então, quando bens 
industriais que poderiam ser produzidos na região periférica, para sua demanda local, não foram. Tanto a inibição quanto o bloqueio estão associados à existência de barreiras à entrada na produção por unidades produtoras no polo paulista. Por fim, os efeitos de destruição surgem, durante a fase da industrialização restringida (1930-1950), com a incapacidade da indústria das regiões em competir com a indústria do polo.

Apesar desses efeitos de eliminação ou bloqueio nas regiões periféricas, segundo Cano (2007b), é de se esperar que os efeitos de estímulo tenham prevalecido com uma dinâmica industrial expressiva nessas regiões, ainda que em menor medida do que aquela presenciada em São Paulo: "o comércio inter-regional, além de demonstrar alterações qualitativas e quantitativas importantes do processo de integração do mercado nacional, mostra que a periferia experimentou um processo de crescimento econômico, não se podendo falar em estagnação regional" (Cano, 2007b, p. 213).

Se, ao menos durante o primeiro período da industrialização por substituição de importação, a periferia no Brasil apresentou um crescimento industrial expressivo ${ }^{6}$ e complementar ao de São Paulo, como explicar, então, as origens do "atraso" econômico dessas regiões, a pobreza, a desigualdade, além de tantos outros males do subdesenvolvimento?

Quando surgiu, a partir da Crise de 1929, a oportunidade para que as economias periféricas mais atrasadas se integrassem ao processo de formação nacional, defrontaram-se com a economia paulista, de base capitalista mais avançada e de diversificada estrutura produtiva, e com outras regiões que, embora com menor desenvolvimento do que o de São Paulo, tinham, entretanto, melhores condições para aquela integração, como foi o caso de Minas Gerais, do Sul e do CentroOeste. (...) Nas regiões mais atrasadas, as débeis estruturas econômicas e as precárias relações capitalistas de produção impediram-lhes a competição mais favorável no processo de industrialização. Por outro lado, até a etapa histórica recente, não puderam oferecer maior "espaço econômico" para que o capitalismo nacional ali penetrasse de forma mais decisiva, acelerando suas transformações e modernizando-as. (...) Dessa forma, a despeito de certa penetração do capital industrial em tais regiões, ali persiste um "espaço" comandado pelo capital mercantil, que obstaculiza o progresso e mantém o atraso (Cano, 2007b, p. 257).

O algoz das regiões periféricas, então, passa a ser o capital mercantil, oriundo (ou junto) “das débeis estruturas econômicas e as precárias relações capitalistas de produção". Como dito, um dos objetivos da tese de Wilson Cano é afastar a interpretação de que o atraso das regiões periféricas se deve à espoliação do "imperialismo sanguessuga" paulista. Essa interpretação cria “(...) a falsa e equivocada impressão de que o problema é um 'conflito entre estados da Federação', passível de solucionar sem que seja necessário mudar o caráter da política econômica e social global. Significa, mais precisamente, não levar em conta o problema da pobreza e da miséria" (Cano, 2007b, p. 312, itálico do autor).

A questão que surge imediatamente é: como o capital mercantil nas regiões periféricas subordina a penetração do capital industrial, limitando a disseminação de seus efeitos modernizantes, e resulta na manutenção do problema da pobreza e da miséria? De antemão, cabe ressaltar que o

(6) “A rigor, não se pode falar em estagnação industrial em nenhuma das regiões brasileiras. Mesmo o Nordeste, de maior pobreza absoluta e relativa, teve nos últimos 51 anos (1919-70), taxa média anual de crescimento industrial de 5\%. Alta, se confrontada com qualquer país capitalista" (Cano, 2007b, p. 95). 
próprio Wilson Cano (2007b, p. 10) reconhecia que esse tema constituía uma lacuna na sua tese: "Eles [setor terciário e construção civil] desempenharam (e ainda desempenham) importante papel na dinâmica de várias regiões. Trata-se, aliás, do reduto preferencial do capital mercantil regional e nacional, que está por merecer estudos mais acurados (Wilson Cano, 2007b [1985], p. 10)”. De fato, sem pretender analisar teoricamente o papel do capital mercantil no subdesenvolvimento econômico, Wilson Cano $(2007 b ; 2010)$ propôs indicar sua atuação nos espaços territoriais "mais atrasados ou em espaços subdesenvolvidos", tendo como referência a região nordestina e a área urbana brasileira.

Historicamente, o capital mercantil precede o capital industrial, compreendendo formas comerciais e usuárias que se apropriam do excedente pela circulação. Mesmo com a dominação do capital industrial “(...) aquela forma inicial não desaparece: algumas frações metamorfoseiam-se em capital produtivo, ao penetrarem na órbita da produção, uma segunda parte permanecerá enquanto tal, subordinadas agora pelo novo, o capital industrial, e outras assumirão outras funções especializadas, por exemplo, como a do capital imobiliário" (Cano, 2010, p. 30, destaque nosso).

O capital mercantil pode assumir formas e se desdobrar em diversas frações, tanto na área rural, quanto no espaço urbano pelo capital imobiliário (Cano, 2007b, p. 257). Em comum está o fato de que sua rentabilidade está assentada no controle sobre o financiamento da produção, na circulação das mercadorias, na armazenagem e/ou pela especulação imobiliária, pelo papel que exercem na estrutura fundiária das regiões. Em síntese, pela apropriação de lucros baseados na circulação e não na produção de valor. O domínio do capital mercantil nas regiões mais atrasadas é retroalimentado pela hegemonia de grupos políticos que aparelham as principais estruturas de poder da região, limitando os efeitos modernizadores do capital industrial.

O grande inimigo do capital mercantil é a urbanização e o capital industrial moderno, público ou privado que penetra nesses espaços e expulsa o capital mercantil:

Ele expulsa porque entra e desmantela uma estrutura de comercialização; rompendo com aquele esquema financeiro anterior, arrebenta com a técnica arcaica pré-capitalista, que está sendo usada naquele momento e ele modifica por dentro aquela região, desencadeando um processo de transformação. Impondo a introdução de forças produtivas capitalistas, que assalaria o trabalho, produz máquinas, tecnifica, inova, inventa, na verdade, uma outra agricultura, uma outra agroindústria e outras relações sociais de produção, ampliando a urbanização (Cano, 2010, p. 40).

Contudo, mesmo com a industrialização, o capital industrial e o Estado brasileiro não conseguiram eliminar o domínio do capital mercantil em muitos desses espaços. Segundo Cano (2010, p. 41), esse limite se deve, muitas vezes a: a) o volume de capital em uma dada região controlada pelo capital mercantil; b) "porque o novo capital modernizador, já atendidas suas necessidades específicas, acomoda seus interesses com os do capital mercantil que ali ainda restou". De todo modo, somente o Estado Nacional é capaz de promover de fato o declínio do capital mercantil, desde que tenha interesse e seja instrumentalizado a isso.

Sem diminuir as valorosas contribuições das suas obras - e elas foram várias, desde o tratamento empírico dos dados, até a análise crítica da questão regional enquanto contraparte do subdesenvolvimento econômico - compete também submetê-las à análise crítica, as quais modificam sensivelmente algumas das teses de Wilson Cano. Uma delas diz respeito à maior dinâmica industrial de São Paulo se originando do maior desenvolvimento capitalista do complexo cafeeiro. 
Evidentemente que o assalariamento, a rede de transportes, os estabelecimentos bancários, a produtividade das terras, a concentração da produção de café, entre outros, constituíram fatores fundamentais para a impressionante geração da riqueza no complexo cafeeiro e, posteriormente, para transferência dela para os setores industriais.

Contudo, uma parte desse crescimento do café paulista se deu, também, por meio da apropriação de valor das outras regiões cafeeiras. Ainda que a maior e a mais produtiva, São Paulo não era a única região produtora de café: em 1920, os cafeeiros paulistas representavam 46,4\% da área cultivada nacional, que compreendia 2.215,7 mil hectares (Cano, 2007a, p. 290). Ora, por ser assentada em uma produção agrícola, dependente da terra, enquanto mercadoria monopolizável com diferentes níveis de produtividade devido à localização, fertilidade e/ou maior inversão de capital, a lucratividade das lavouras cafeeiras paulistas se deu com a transferência de valor dos outros produtores cafeeiros menos produtivos. Tem-se aqui a categoria da renda terra enquanto parcela do lucro extraordinário capturado pelo proprietário fundiário e, portanto, presente na órbita da circulação ou, nos termos de Cano, do capital mercantil. Nesse aspecto específico, que merece maiores investigações, cabem três advertências de Marx (2017, cap. 38, tomo III, s.p.) sobre a renda da terra que auxiliam a entender o processo de conversão do lucro extraordinário em renda da terra:

Primeiro: essa renda, evidentemente, é sempre diferencial, pois não entra de maneira decisiva no preço de produção geral da mercadoria, mas o pressupõe. Ela deriva da diferença entre o preço de produção individual do capital individual, que tem à disposição a força natural monopolizada, e o preço de produção geral do capital investido nessa esfera de produção.(...) Segundo: essa renda fundiária não tem origem no aumento absoluto da força produtiva do capital empregado nem do trabalho por ele apropriado - aumento que, em geral, só pode reduzir o valor das mercadorias -, mas da maior produtividade relativa de determinados capitais individuais investidos numa esfera da produção, em comparação com os investimentos de capital excluídos dessas condições favoráveis excepcionais, criadas pela natureza, da força produtiva. (...) Terceiro: a força natural não é a fonte do lucro extra, mas apenas uma base natural dele, uma vez que é a base natural da força produtiva excepcionalmente elevada do trabalho. (...) Se os diferentes valores não se compensassem para formar os preços de produção nem os diversos preços individuais de produção o fizessem para formar um preço de produção geral, regulador do mercado, o simples aumento da força produtiva do trabalho mediante o uso da queda-d'água apenas reduziria o preço das mercadorias produzidas dessa maneira, sem elevar a parte do lucro incluído nessas mercadorias.

De forma semelhante, outra tese que pode ser questionada diz respeito à concorrência intercapitalista dentre as unidades federativas durante a industrialização restringida, e a dominação dos mercados por São Paulo. Mais uma vez, a crítica se direciona à posição autocentrada da economia paulista, sem levar em conta o processo de produção e apropriação do mais-valor entre os ramos de produção. Por mais vultosa que fosse a "dinâmica capitalista paulista", a partir do momento que em 1930 se acelera a formação de uma economia capitalista nacional, com maiores liberdade de circulação de força de trabalho, capital e mercadoria (vide a luta pelo fim dos impostos estaduais pelos industriais), a concorrência capitalista e formação de uma taxa de lucro média, tendencialmente, implicam a transferência de valor em setores que operam com menor composição orgânica do capital 
(regiões) para aqueles de maior composição (São Paulo). E, portanto, é evidente que mediados pela concorrência intercapitalista e intersetorial, ocorre transferência de valor a nível regional ${ }^{7}$.

O lucro médio do capitalista individual, ou de cada capital particular, é, como vimos, determinado não pelo mais-trabalho, de que esse capital se apropria em primeira mão, mas pela quantidade total de mais-trabalho de que o capital inteiro se apropria e do qual cada capital particular extrai seus dividendos como alíquota do capital total (Marx, 2017, cap. 36, s.p.)

É extremamente relevante retomar esse debate, um pouco apagado nas últimas décadas, inclusive pelo sucesso da interpretação de Cano. Politicamente há uma certa preocupação em se denunciar a espoliação interna em favorecimento dos paulistas para não isentar as elites das regiões das áreas atrasadas da responsabilidade pelo seu próprio atraso. Por isso a ênfase no capital mercantil, que seria resultado somente local. Mas esse argumento poderia, em um nível mais abstrato, invalidar a própria teoria do subdesenvolvimento que também coloca ênfase nas deteriorações dos termos de troca (setor externo). Ademais, é importante lembrar que, como vimos, Cano admite a "dominação" da economia paulista sobre as demais economias regionais, mas ao mesmo tempo defende que no balanço geral os efeitos positivos foram superiores aos negativos. Estar-se-ia, então, diante de um curioso caso em que a dominação é benéfica aos dominados.

Por fim, cabe considerar criticamente o capital mercantil. Conforme visto, o capital mercantil opera, sobretudo na circulação, se apropriando nos espaços mais subdesenvolvidos de excedentes que poderiam ser direcionados para o capital industrial. Do ponto de vista da crítica da economia política, a noção de capital mercantil se apresenta de maneira confusa. Em alguns momentos, o capital mercantil parece fazer referência ao capital-mercadoria $\left(M^{\prime}\right)^{8}$, enquanto forma autônoma do capital no processo de circulação de capital industrial, juntamente com o capital-dinheiro (D) e o capital produtivo (P), conforme tomo II d'O Capital de Marx. Se assim for, a noção não parece ter correspondência com o fenômeno histórico apontado por Cano, uma vez que o capital-mercadoria não se valoriza pela apropriação do excedente durante a conversão da fase produtiva para a retomada em dinheiro.

Em outros momentos, capital mercantil parece ser sinônimo de ramos de produção (agrícola, armazenagem, construção, "terciário"). Ainda, pode ser apenas uma atitude moralista condenável, de um capital se valorizando de forma "selvagem" por maior exploração da força de trabalho, depredação da natureza ou relação espúria com o poder público.

Paradoxalmente, a única passagem mais precisa e definidora do capital mercantil comumente associada só tem referência, em Marx, no momento que antecede à produção tipicamente capitalista. Depois da sua plena constituição, a valorização do capital passa a ter como referência uma taxa média de lucro, o que circunscreve a apropriação direta do capital mercantil do valor criado:

No decurso da análise científica, a formação da taxa geral de lucro aparece como se emanasse dos capitais industriais e de sua concorrência e como se só mais tarde fosse corrigida, complementada e modificada em virtude da ingerência do capital comercial. No curso do desenvolvimento histórico, ocorre exatamente o inverso. É o capital comercial que primeiro

(7) Apenas para explicitar esse ponto, Wilson Cano não nega a questão da transferência de riqueza e força de trabalho entre as regiões como um aspecto importante nas das desigualdades, mas subalterniza o fenômeno analiticamente.

(8) Em espanhol, a tradução do capital-mercadoria é capital mercantil, por exemplo. 
determina o preço das mercadorias mais ou menos conforme o valor delas, sendo a esfera da circulação - mediadora do processo de reprodução - o lugar onde se forma uma taxa geral de lucro. O lucro comercial determina originariamente o lucro industrial. É apenas depois de ter-se imposto o modo de produção capitalista e de o próprio produtor tornar-se comerciante que o lucro comercial é reduzido à alíquota do mais-valor total, que corresponde ao capital comercial como alíquota do capital total empregado no processo social da reprodução (Marx, 2017, cap. 17, s.p.)

Nessa visão sintética do pensamento de Wilson Cano sobre a questão regional, procurou-se evidenciar como suas investigações compartilham, metodologicamente, a tradição cepalina históricoestrutural e se projetam, de forma original, sobre a análise dos dilemas nacionais em um nível espacial mais específico, no caso, regional/urbano. De fato, ao procurar recompor as origens da questão regional com o avanço da industrialização, e, posteriormente com a desindustrialização, a obra de Wilson Cano incorpora a constituição da economia nacional e efeitos e condicionantes econômicos sobre as regiões. Diferentemente de muitos economistas que subalternizam a questão regional, ou a encaram como mera curiosidade ou folclore, para Wilson Cano, os desequilíbrios regionais constituem mais uma face do subdesenvolvimento econômico e devem ser corretamente analisados para, em seguida, ser denunciados e combatidos. Com o neoliberalismo, essa tarefa se mostra ainda mais urgente.

\section{Ofensiva ideológica neoliberal e propostas para resistência}

\subsection{A dominação ideológica}

O nível de regressão a que foi submetida a economia da América Latina durante o período neoliberal teve também seu correspondente na dimensão ideológica anotada por Wilson Cano. As discussões estratégicas e nacionais perderam significância para a maioria dos economistas que ficaram acorrentados ao curto prazo, discutindo "tão somente a conjuntura, o juro, os preços, o câmbio e o salário" (Cano, 1999, p. 298).

A maior parte dos economistas e dos acadêmicos abandonou suas preocupações de longo prazo, de crescimento e desenvolvimento, tornando-se "curtoprazistas", centrando sua produção sobre o câmbio, os juros, a inflação, a região e a cidade competitiva. A partir da década de 1990, sobressaíram, em especial, os estudos sobre finanças, metas de inflação e produto potencial e equivocadas análises sobre o produto interno bruto (PIB) municipal, em que pontificaram a modelística e uma alta dose de estéril econometria (....) (Cano, 2011, p. 327).

Mesmo os economistas críticos foram encarcerados nessa lógica curtoprazista de forma que reivindicações mais imediatas foram sendo rebaixadas em virtude do pragmatismo:

Por exemplo, a longa e pronunciada deterioração do salário mínimo legal em quase todos os países da região já não é mais contestada plenamente, a despeito de se poder e saber calcular a dimensão de sua corrosão de longo prazo. A plena restauração de suas perdas poderia causar tal impacto que até mesmo lideranças de esquerda e sindicais não a reivindicam mais (Cano, 1999, p. 313).

Mais grave ainda foi a conversão explícita de muitos economistas ao ideário neoliberal que acabou se tornado corrente hegemônica no debate público e no ensino das escolas de economia. 
Assim, se na década de 1980 a maior parte dos economistas se omitiu para com os problemas do longo prazo e do desenvolvimento, ou seja, do futuro do país, fez pior a partir da de 1990, ao declarar seu credo ao neoliberalismo. Da omissão passaram à participação ostensiva nesse mar de equívocos, nesse fatal esquecimento de que somos subdesenvolvidos - e não "emergentes", como disseram os neoliberais. Não se podem esquecer os "equívocos" crassos cometidos na política de privatização, ou dos quase US\$ 200 bilhões que torramos, entre 1995 e 2002, com nossa "inteligente e eficiente" política cambial. Se, entre 1990 e 2002, o presidencialismo ocultou o poder de fato do Banco Central do Brasil (Bacen), devemos ter em conta que, após essa data, esse poder foi ostensivamente dado a público. Esse Estado e esses economistas acabaram por aceitar como inevitáveis a desnacionalização, a desindustrialização e a continuidade do poder de fato do sistema financeiro. (...) Mas esses comportamentos não se restringiram à análise e à política econômica. Também copiaram, mais uma vez, muito do ruim que se produziu na teoria: o papel das reformas neoliberais - o Consenso de Washington -, o neoinstitucionalismo, o neoestruturalismo, os modelos de convergência internacional, a maior parte dos modelos de crescimento endógeno e muitas das "novas teorias" do desenvolvimento. De desenvolvimentistas de ontem, passaram a inimigos do elevado crescimento; de industrialistas, passaram a aceitar a reprimarização de nossa pauta exportadora. Trocaram a estratégia do protecionismo necessário pela estultice da abertura internacional dos mercados de commodities, em troca de nosso imprescindível mercado interno de manufaturados. E, mais curioso ainda, se esforçaram para ampliar o Mercado Comum do Sul (Mercosul), ao mesmo tempo em que endossaram a contraditória ideia do regionalismo aberto, "missão impossível" do novo pensamento da Comissão Econômica para a América Latina e o Caribe (Cepal) (Cano, 2011, p. 327-328).

E evidentemente essa regressão ideológica retroalimenta a regressão econômica e política, já que influencia as tomadas de decisões: "Se compararmos nossas 'tomadas de decisões' de hoje, em relação ao ingresso dos investimentos externos, com as que tomávamos à época das políticas de 'substituição consciente de importações', a diferença é radical" (Cano, 1999 p. 310). E são essas tomadas de decisões que levaram a abandonar o desenvolvimento econômico e têm nos aprisionado a uma crise estrutural que já alcança quatro décadas.

Não apenas abandonamos os rumos de nosso possível desenvolvimento, mas também agravamos o processo de desindustrialização do país, fato que tenho denunciado há vários anos, mas que, para muitos economistas - mesmo para alguns "progressistas" -, o fenômeno seria menos importante. E, para comprovar suas (falsas) teses, citam Austrália, Nova Zelândia e Canadá (!) como países agrícolas desenvolvidos. Alguns chegam à desfaçatez de dizer que "a industrialização não é mais, como no passado, o motor do desenvolvimento". A ignorância ou a ingenuidade ou, ainda, a má-fé, é muito grande no caso (Cano, 2014, p. 148).

\subsection{Dominação ideológica e questão regional}

$\mathrm{Na}$ fase neoliberal, as fronteiras, as heterogeneidades e as hierarquias são supostamente superadas. Supostamente porque tal ideologia define aprioristicamente o fim destas barreiras para a acumulação de capital. O retorno do liberalismo econômico enquanto ordenamento do capitalismo mundial, após os anos de 1970, se impõe também no campo das ideias, como já colocado na seção anterior. Porém, é preciso colocar mais alguns elementos específicos para análise regional. Cano e Guimarães Neto trazem este debate ainda no final dos anos de 1980: 
A tentativa de um correto entendimento da questão regional passa, no nosso entendimento, pelo estudo do processo histórico das diversas regiões e de suas interrelações, e pelas démarche da acumulação de capital que tente a ocorrer de forma[s] distintas nos diversos espaços econômicos. Isto implica, necessariamente, no abandono das abordagens de corte neo-clássico, centradas, por exemplo, em temas como da base econômica, polarização, etc. (Cano; Guimarães Neto, 1989, p. 170).

Se, por um lado, a economia neoclássica apresenta suas insuficiências teóricas e metodológicas, dada a desvinculação de seus pressupostos com a realidade concreta, uma série de correntes de pensamento nas ciências sociais passam também a estabelecer critérios de análise regional sem os corretos procedimentos que relacionam subdesenvolvimento e questão regional nas economias latino-americanas. Cano (2011) cita como o auge dessa crise do pensamento crítico na América Latina o regionalismo aberto da Cepal. Se observarmos a linha do tempo do pensamento econômico e sociológico latino-americano, realmente perceberemos que passamos de um debate substancial em torno do subdesenvolvimento e da dependência, nos anos de 1960 e 1970, para os debates sobre as receitas neoliberais a serem adotadas pelos governos destes países.

Não ficaria alheio a estas mudanças estruturais na América Latina o pensamento crítico que discute o planejamento regional e urbano. Com a hegemonia da pós-modernidade nas ciências sociais, três frentes metodológicas se tornam hegemônicas nesta área: i) estudos de casos baseados em teorias localistas de desenvolvimento endógeno, que servem, na maioria das vezes para explicar somente o próprio caso e se esquecem das vinculações com outras escalas, como parcialmente evidenciado por Brandão $(2011)^{9}$; ii) estudos comparativos de realidades regionais inseridas na economia brasileira, mas distintas em suas inserções regionais, como é o caso da série de estudos sobre cidades médias ${ }^{10}$; iii) e estudos baseados na lógica de dar nome a categorias que já existem ${ }^{11}$. No limite, a vinculação destes estudos de caso com processos mais gerais da acumulação de capital se limita a copiar conceitos abstratos, como a financeirização, cuja quantidade de utilizações tem sido diretamente proporcional à ausência de rigor teórico e desacoplados da perspectiva do subdesenvolvimento e da dependência.

Depois de tantas décadas de políticas econômicas e pensamentos igualmente liberais hegemonizando boa parte das pautas e dos projetos sociais na América Latina, o centro do debate passam a ser as sequentes crises de reprodução de sociedades capitalistas que já se percebe não serem mais incompletas ou insuficientes, mas excessivamente definidas pelos processos de acumulação de capital. Ensaios sobre a crise urbana do Brasil (Cano, 2011) atesta que o principal elemento da crise

(9) Brandão faz um estudo abrangente em torno das novas teorias do desenvolvimento regional. Para o autor, sua grande maioria está envolta de pressupostos liberais quanto à relação das regiões e das cidades com o capitalismo global. A competição inter-regional e entre cidades globais é um aspecto que deve ser levado em consideração para entendermos o lugar de fala destas abordagens teóricas. Porém, o autor se limita a discutir múltiplas escalas sem, entretanto, reconhecer os limites do desenvolvimentismo. Se aproxima, portanto, ao discutir a importância do Estado, mais a um anacronismo evidente que propriamente a uma proposta de superação das políticas econômicas liberais nos países subdesenvolvidos.

(10) Geógrafos da Universidade Estadual de São Paulo Júlio de Mesquita Filho - Campus de Presidente Prudente são vanguarda neste tipo de estudo comparativo. Cidades do interior do estado de São Paulo são continuadamente comparadas com outras cidades médias de outras regiões do país. São José do Rio Preto e Presidente Prudente são algumas das cidades mais eleitas para estes estudos.

(11) Em um desses estudos, como forma de exemplificar o terceiro tipo de frente metodológica, temos o caso da tese de doutorado de Catelan (2013), cujo título é Heterarquia urbana: interações espaciais interescalares e cidades médias. 
do subdesenvolvimento brasileiro é a própria urbanização, enquanto consequência da tentativa de superação do subdesenvolvimento por meio do processo anterior de industrialização.

Wilson Cano jamais transformou sua análise acadêmica no tratamento da região e do regionalismo de maneira folclórica, alcançando apenas a aparência da relação entre centro dinâmico nacional e periferias. Tratar de forma folclórica significa relegar a questão regional à descrição e enaltecimento de aspectos culturais, desconsiderando que o subdesenvolvimento tem nas distintas formas de inserção das regiões no processo geral de acumulação seus aspectos mais concretos e imediatos.

\subsection{Alternativa ao modelo neoliberal e superação da crise estrutural: agenda de pesquisas e projeto nacional de desenvolvimento}

Assim, desde o início dos anos 1990 que Cano propõe a ruptura radical com o modelo neoliberal e como alternativa defende um programa organizado e defensivo para, por um lado, reverter as regressões produtivas e sociais que adviriam da adoção do modelo neoliberal, por outro, engajar os processos técnicos oriundos da nova revolução industrial (Cano 1990; 1995). O realismo de Cano se expressa na afirmação de que o desenvolvimento econômico não é para todos os povos, já que desenvolvimento e subdesenvolvimento não são etapas de um processo contínuo, mas faces contraditórias de um mesmo processo histórico.

O desenvolvimento é possível para todos os povos? Não, nos ensinou Celso Furtado, mostrando que o subdesenvolvimento não é etapa do desenvolvimento, e sim constitui processo histórico, criado a partir da forma como fomos inseridos na economia capitalista internacional, como produtores de matérias-primas e alimentos e compradores de manufaturados, como economia colonial e, na maior parte dos casos, escravista, características que demarcaram nossa herança histórica e nossas estruturas de poder. Explicou-nos também as questões nevrálgicas do subdesenvolvimento: a má distribuição de renda, fixando determinado perfil da demanda e da estrutura da oferta; e os grandes desequilíbrios estruturais: no balanço de pagamentos, na estrutura fiscal e tributária e no financiamento de longo prazo, além de colossal subemprego e inflação latente. (...) Com nossa história, aprendemos que podemos crescer e amenizar nossos males, mas não atingir os padrões dos países desenvolvidos. Sempre haverá um hiato, principalmente qualitativo, entre nós e eles, que tem crescido expressivamente nos últimos três séculos. (Cano, 2011, p. 336)

Por isso, entre os países subdesenvolvidos alguns poderiam alcançar melhores margens de manobra para negociar a subordinação, devido às suas condições físicas, populacionais e históricas.

Nossa estratégia, portanto, não se refere, como se poderia pensar a uma tentativa urgente e precipitada de buscar outro caminho para o "primeiro mundismo" e para a modernidade. Não é essa a nossa intenção, simplesmente porque sabemos, pelo exame da história, que um país de economia capitalista subdesenvolvida, retardatária como a nossa, não tem condições de se engajar na Revolução Industrial - na Terceira no caso presente - de forma rápida como pretendem os autores do discurso neoliberal. Sabemos que, na verdade, só em parte seremos "primeiro mundistas" e que, portanto, a nossa estratégia terá que se pautar por uma estratégia do possível, por uma estratégia do necessário.(...) Tomados o Segundo e o Terceiro Mundos, creio que apenas alguns poucos países, como China, Rússia, Brasil e Índia, por suas dimensões econômicas e 
espaciais, suas capacidades produtivas e suas dotações de recursos, têm condições de amenizar os efeitos dessa "globalização", negociando a subordinação - parcial e relativa - da modernização produtiva às suas condições econômicas e sociais atuais e a uma política de desenvolvimento a longo prazo, com justiça social. Contudo, as forças políticas de direita têm predominado na maioria dos países, anulando suas capacidades de resistência. Por exemplo, no Brasil, o impeachment de Fernando I (Collor), que aqui introduziu as políticas neoliberais, não impediu a vitória de Fernando II (FHC), que as aprofundou ainda mais (Cano, 1996, p. 135).

Cano soube que tal engajamento dependeria de um esforço nacional consciente e planejado que demoraria décadas e seria ainda mais agravado pela nova ofensiva imperialista, uma verdadeira avalanche à qual poucas economias, entre elas a brasileira, conseguiriam impor alguma resistência. Como se sabe esse programa não foi adotado, ao contrário, a partir dos anos 1990 o Brasil integrou a ofensiva neoliberal como um de seus protagonistas periféricos. Assim, o nível de regressão produtiva, social e ideológica foi aprofundado.

Mas o modelo neoliberal é completamente insuficiente para solucionar nossos problemas nacionais e se revela como tal ano após ano, década após década. Por isso nos últimos anos Cano dedicou sua atividade intelectual para retomar "nossa soberania econômica perdida" (Cano, 2011, p. 362), o que exigiria um profundo conhecimento dos problemas nacionais, conformando uma "agenda de pesquisas", e das distintas alternativas de solução, que conformariam um novo "plano nacional de desenvolvimento" capaz de enfrentar a crise estrutural a que estamos submetidos. Este projeto teria "como vetor político central o ataque frontal a nossas desigualdades maiores e uma verdadeira estratégia de retomada da industrialização, com vista a um crescimento econômico mais bem ambientalmente sustentado" (Cano, 2011, p. 358). Por isso, deveria priorizar o mercado interno, tendo como principais atividades contempladas "setor habitacional, priorizando no tempo o segmento popular; saneamento básico; educação, cultura e saúde públicas; e bens de primeira necessidade”; e como segundo vetor de desenvolvimento a produção para exportações industriais (Cano, 2011, p. 363).

O que se mantém na abordagem do professor Wilson Cano nos anos mais recentes é a insistência em reivindicar reformas estruturais e nova orientação da política econômica para superação do subdesenvolvimento. Reformas estas que devem estar alinhadas a um esforço nacional de desenvolvimento econômico. Cano percebe com bastante nitidez a insuficiência da modernização conservadora no campo sem uma reforma agrária ampla e popular que altere o modelo agrícola brasileiro. Percebe também que sua contrapartida é o caos urbano instalado em todas as metrópoles nacionais, do centro dinâmico da economia nacional às metrópoles regionais das periferias do país, como bem colocado em seus textos mais recentes (Cano, 2011).

A questão que deixa em aberto é quem serão os atores sociais protagonistas desse projeto organizado e defensivo, se toda a interpretação desenvolvimentista se apoiava na capacidade da elite industrial, particularmente paulista, de dirigir esse processo em aliança com os trabalhadores assalariados. O que vimos reiteradamente ao longo das últimas três décadas é o completo abandono por parte do que resta dessa elite industrial e paulista do desejo de desenvolvimento nacional, tal como prognosticava o próprio Cano: 
Por outro lado, continuando no campo das dificuldades internas cabe lembrar que as nossas elites, ainda não refeitas do fracasso do "Brasil Potência" e do II PND, e conservadoramente adaptadas ao jogo da "ciranda" financeira pública e da usura fácil - onde estiveram por mais de 10 anos ganhando mais dinheiro no mercado financeiro do que produzindo bens e serviços - , se encontram hoje atônitas, perplexas, sem um projeto nacional, correndo inclusive o risco de se converterem meramente em elites mercantis e usurárias, caso venha a prevalecer uma regressão econômica decorrente da liberalização da economia nacional, diminuindo seu grau de industrialização e remercantilizando a economia (Cano, 1990, p. 137).

Nota-se que essa elite não somente abandonou, mas se tornou inimiga dessa estratégia desenvolvimentista que permanece somente em parte do movimento sindical trabalhista e na cabeça de economistas heterodoxos.

\section{Conclusões}

Cano se estabelece como herdeiro da abordagem cepalina na análise do subdesenvolvimento latino-americano. Há, em seus escritos, uma preocupação em relacionar vários níveis de abstração a partir do espaço e dos territórios, sem perder de vista os determinantes gerais da acumulação de capital, traduzidos em sua preocupação com a periodização do desenvolvimento capitalista da região. Mesmo diante da avalanche ideológica associada ao neoliberalismo, quando o projeto de industrialização foi atacado sistematicamente, sobretudo pelos economistas, Wilson Cano não abdicou do rigor teórico e da postura política para denunciar que a liberalização comercial financeira e a redução do papel do Estado aprofundariam o subdesenvolvimento econômico. Como também discutido, essa postura do professor revelava uma tática política específica baseada, por sua vez, na melhor tradição teórica do pensamento estruturalista latino-americano.

Suas virtudes também devem ser analisadas criticamente e deve-se questionar até que ponto ocorreu a superação das limitações estratégicas demonstradas pelo desenvolvimentismo dos anos 1960. Assim como os cepalinos na conjuntura dos anos de 1950, sua proposta pressupõe um conjunto de forças políticas num amplo arco de "forças nacionais" a reverter essa situação. Entre elas, estariam frações importantes das classes dominantes, condição essa que não encontra respaldo no atual estágio de dependência Latino Americana. Obviamente, essa situação não passava desapercebida por Wilson Cano. Para ele, a solução desse nó górdio do subdesenvolvimento econômico brasileiro, na atual conjuntura neoliberal, era hipertrofiar o papel do Estado Nacional, dotando-o de recursos financeiros e humanos que permitissem se contrapor à valorização do capital rentístico por parte das elites nacionais e estrangeiras.

Mas então a pergunta anterior retorna: quais seriam as forças sociais a suportar tal Estado? Caberia exclusivamente às classes subalternas realizar a tarefa histórica de conduzir um projeto capitalista de desenvolvimento? Ou estaríamos diante da necessidade histórica de formular um outro projeto de desenvolvimento? As contribuições de Cano nos colocam nesse debate, ao qual à realidade subdesenvolvida adiciona a urgência por respostas teóricas e práticas. Chamá-lo de desenvolvimentista no Brasil, maior dos sócios do império no sul global, é reconhecê-lo revolucionário. Reafirmar isso diante do neoliberalismo é diferenciá-lo do desenvolvimentismo vulgar, alheio ao rigor de quem conhece as especificidades dos processos históricos de cada território que compõe a América Latina. 
A despeito das valorosas contribuições das suas obras - e elas foram várias, desde o tratamento empírico dos dados, até a análise crítica da questão regional enquanto contraparte do subdesenvolvimento econômico - a abordagem de Cano na temática espacial se depara com limitações. A análise do processo histórico e espacial de constituição da economia dependente latinoamericana evidencia que as desigualdades e as mazelas sociais e econômicas nos diversos territórios não podem ser superadas no capitalismo dependente, enquanto a transferência internacional de valor e a superexploração da força de trabalho ainda constituírem as estruturas básicas dessas economias. Mais do que isso, o próprio desenvolvimento capitalista dependente amplia as desigualdades pelo território, a partir de um padrão de reprodução, circulação e apropriação de capital.

A questão básica, então, não é tanto entender os desequilíbrios regionais conforme diferentes níveis de crescimento das regiões e dos setores, mas sim, como o crescimento da economia capitalista dependente espolia a natureza e superexplora a força de trabalho de maneiras distintas pelo território, desencadeando fluxos de produção e circulação de valor de forma desiguais, mas dentro da unidade totalizante da economia dependente. $\mathrm{O}$ capitalismo dependente mantém, cria e recria setores cuja lucratividade passa a depender cada vez mais da superexploração e degradação ambiental, sobretudo nas regiões periféricas, com setores de baixa composição orgânica do capital. O inimigo não é a parte, mas o todo, não é o capital mercantil, mas o capitalismo dependente em si.

\section{Referências bibliográficas}

BIELSCHOWSKY, Ricardo (Org.). Cinquenta anos de pensamento na Cepal. Tradução de Vera Ribeiro. Rio de Janeiro: Record, 2000. v. 1 e 2.

BRANDÃO, Carlos Antônio. Território e desenvolvimento: as múltiplas escalas entre o local e o global. 2011.

CANO, Wilson. América Latina: do desenvolvimento ao neoliberalismo. In: FIORI, José Luís. Estados e moedas no desenvolvimento das nações. Petrópolis: Vozes, 1999, p. 287-326.

CANO, Wilson. Brasil: crise e alternativas ao neoliberalismo. In: CANO, Wilson. Reflexões sobre o Brasil e a nova (des) ordem internacional. Campinas: Ed. Unicamp, 1995.

CANO, Wilson. Raízes da concentração industrial em São Paulo. 5. ed. Campinas: Unicamp/IE, [1975] 2007a.

CANO, Wilson. Desequilíbrios regionais e concentração industrial no Brasil, 1930-1970. Unesp, [1985] 2007b.

CANO, Wilson. Desconcentração produtiva regional do Brasil: 1970-2005. São Paulo: Editora Unesp, 2007c.

CANO, Wilson. Furtado: a questão regional e a agricultura itinerante. In: CANO, Wilson. (Org.). Ensaios sobre a formação econômica regional do Brasil. Campinas: Editora da Unicamp, 2002. p. 117-148.

CANO, Wilson. Notas sobre o imperialismo hoje. Crítica marxista, v. 1, n. 3, 1996, p 132-135. Disponível em: https://www.ifch.unicamp.br/criticamarxista/arquivos biblioteca/debate14deb1.2.pdf. 
Evaldo Gomes Júnior, Pietro Caldeirini Aruto, Vitor Hugo Tonin

CANO, Wilson. Novas determinações sobre as questões regional e urbana após 1980. Revista Brasileira de Estudos Urbanos e Regionais, v. 13, n. 2, p. 27-53, 2011. Disponível em: https://rbeur.anpur.org.br/rbeur/article/view/393/369.

CANO, Wilson. Proposta para análise e enfrentamento da crise estrutural do modelo econômico. Crítica Marxista, v. 38, 2014, p 147-156. Disponível em: https://www.ifch.unicamp.br/criticamarxista/arquivos_biblioteca/documento2015_06_10_18_15_02 54.pdf.

CANO, Wilson. Reflexões sobre o papel do capital mercantil na questão regional e urbana do Brasil. Soc. Bras. Economia Política, n. 27, p. 29-57, 2010.

CANO, Wilson. Uma Agenda Nacional para o Desenvolvimento. In: CANO, Wilson. Ensaios sobre a crise urbana do Brasil. Campinas: Editora Unicamp, 2011.

CANO, Wilson. Uma alternativa não neoliberal para a economia brasileira na década de 1990. In: CANO, Wilson (Coord.). São Paulo no limiar do século XXI. São Paulo: Fundação SEADE, 1990, v. 1 , p. $124-151$.

CANO, Wilson; GUIMARÃES NETO, Leonardo. Questão regional no Brasil: evolução histórica. Pensamiento Iberoamericano, Madri, v. 2, 1986. Disponível em: https://1e6b71fa-c892-4e13-ba26a09d48537b8d.filesusr.com/ugd/13f1ee 65bcff6fc6954c96ab455fccc64e6e90.pdf.

CARDOSO, Fernando Henrique; FALETTO, Enzo. Dependência e desenvolvimento na América Latina. In: BIELSCHOWSKY, Ricardo (Org.). Cinquenta anos de pensamento na Cepal. Tradução de Vera Ribeiro. Rio de Janeiro: Record, 2000. v. 2.

CATELAN, Márcio José. Heterarquia urbana: interações espaciais interescalares e cidades médias. Cultura Acadêmica, 2013. Disponível em: https://repositorio.unesp.br/bitstream/handle/11449/105058/catelan_mj_dr_prud.pdf?sequence=1.

FRANK, Andre Gunder. The development of underdevelopment. Monthly Review, v. 18, n. 4, set. 1966. Disponível em: https://monthlyreviewarchives.org/index.php/mr/article/view/MR-018-041966-08 3.

FURTADO, Celso. Uma política de desenvolvimento econômico para o Nordeste. Grupo de Trabalho para o Desenvolvimento do Nordeste (GTDN). Conselho do Desenvolvimento. Rio de Janeiro: Departamento de Imprensa Nacional, 1959. (Texto não assinado pelo autor, mas de autoria confessa).

HOBSON, John Atkinson. A evolução do capitalismo moderno: um estudo da produção mecanizada. São Paulo: Nova Cultural, 1985.

LÊNIN, Vladimir Ilitch. O imperialismo: fase superior do capitalismo. 3. ed. São Paulo: Centauro, 2005.

MARINI, Ruy Mauro. Presentación. In: MARINI, Ruy Mauro; Millán, Márgara (Coord.). La teoría social latinoamericana tomo II: subdesarrollo y dependencia. 2. ed. Cidade do México: El Caballito 1999, p. 11-14. 
MARX, Karl. O capital [recurso eletrônico]: crítica da economia política: livro III: o processo global da produção capitalista. Edição de Friedrich Engels. 1. ed. Tradução Rubens Enderle. São Paulo: Boitempo, 2017.

MELLO, João Manuel Cardoso de. O capitalismo tardio: contribuição à revisão crítica da formação e desenvolvimento da economia brasileira. 8. ed. São Paulo: Editora Brasiliense, [1975] 1982.

TAVARES, Maria da Conceição. Da substituição de importações ao capitalismo financeiro: ensaios sobre economia brasileira. Coleção Biblioteca de Ciências Sociais. Rio de Janeiro: Zahar Editores, 1972.

TAVARES, Maria da Conceição. Auge e declínio do processo de substituição de importações no Brasil. In: BIELSCHOWSKY, Ricardo (Org.). Cinquenta anos de pensamento na Cepal. Tradução de Vera Ribeiro. Rio de Janeiro: Record, 2000. v. 1. 